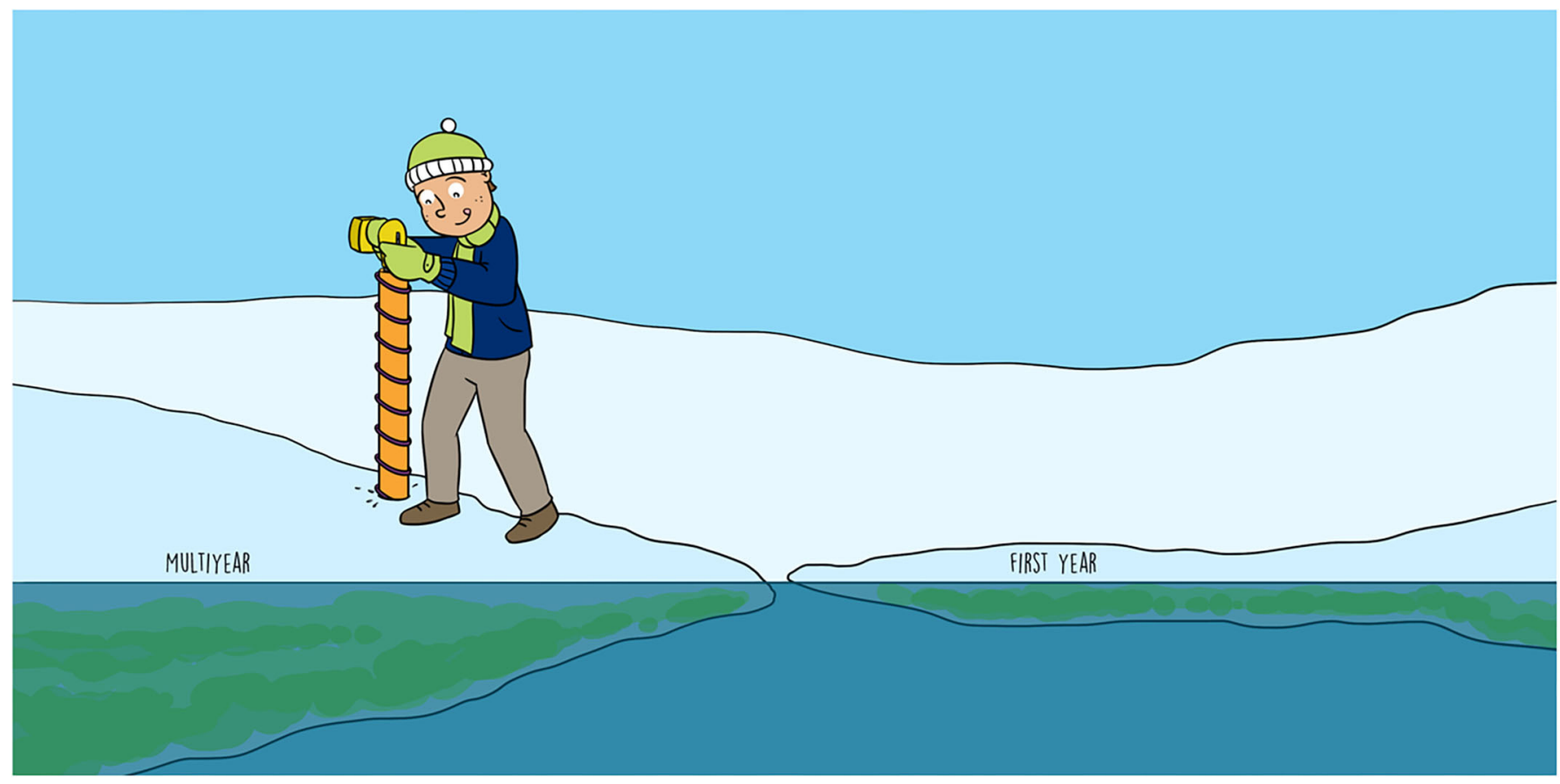

\title{
HOW MELTING ARCTIC SEA ICE CAN LEAD TO STARVING POLAR BEARS
}

\section{Doreen Kohlbach * and Benjamin A. Lange}

Norwegian Polar Institute, Framsenteret, Tromsø, Norway

YOUNG REVIEWERS:

DEVONPORT

HIGH

SCHOOL

FOR GIRLS

(11C/2020)

AGES: $15-16$
Sea ice is an important habitat for many organisms, from the microscopic up to large mammals like seals and polar bears. Small animals called zooplankton can feed directly on microscopic plant-like sea-ice algae. Larger animals, such as fish can, in turn, feed on zooplankton, seals feed on fish and larger zooplankton, and polar bears hunt seals. In this way, energy is transferred from algae all the way up the food chain to polar bears. Rising temperatures have resulted in changes to Arctic sea-ice habitats. These changes will affect top predators' habitats for hunting, feeding, and breeding, and will change the energy transfer from sea-ice algae up through the food chain. By studying the fat content of algae and animals, we found that sea-ice algae ensure the survival of many Arctic animals. Thus, changing sea-ice habitats can result in empty stomachs for zooplankton and, consequently, for top predators. 


\section{SEA-ICE ALGAE}

Algae that live within the sea ice, mainly close to the sea ice-water interface.

\section{SEA ICE: A COZY HOME FOR MICROSCOPIC ORGANISMS}

During autumn and winter, the extremely low temperatures in the Arctic result in the formation of sea ice that floats on the ocean surface. Due to the presence of salt in seawater, small pockets, called brine channels, are formed within the sea ice. These brine channels are very important features of sea ice, because they enable plants and animals to live in, and to move throughout, the ice. One group of microscopic plant-like organisms growing within and underneath the sea ice is called sea-ice algae. To grow and reproduce, sea-ice algae require light for photosynthesis. In photosynthesis, the algae absorb carbon dioxide $\left(\mathrm{CO}_{2}\right)$ from the ocean and atmosphere and transform it into fats and sugars, using energy from sunlight. These compounds serve as an energy source for organisms that feed on sea-ice algae. During Arctic winter, there is not enough light for photosynthesis, so algae cannot grow. In spring, the light increases, and sea-ice algae grow rapidly, which is referred to as the ice-algal bloom. The higher temperatures in spring soften the sea ice and the bottom ice starts to melt. Sea-ice algae in the bottom of the sea ice are then released into the water, where they are eaten by highly specialized animals, called grazers.

Thirty years ago, the Arctic Ocean was dominated by very old, thick sea ice called multiyear ice. Multiyear ice is ice that has survived one or more summer melt seasons (Figures 1a,c). Most of this multiyear ice was 5-10 years old and reached thicknesses over $10 \mathrm{~m}$. Today, this old, thick, multiyear ice has almost disappeared, and the remaining multiyear ice is dominated by 2-4-years-old ice with 2 to $5 \mathrm{~m}$ ice thickness [1]. This remaining multiyear ice is now found primarily in a small area between Canada, Greenland, and the North Pole-the so-called Last Ice Area. As the Arctic sea-ice habitat continues to change, the Last Ice Area may become an important refuge for animals that depend on sea ice for survival.

Because of its presence year-round, multiyear ice is a particularly important habitat within the Arctic ecosystem [2]. Due to climate change, however, multiyear ice is being replaced by thinner, younger sea ice called first-year ice. This is sea ice that has NOT survived a summer melt season and is thus $<1$ year from formation (Figures $1 a, b)$. Multiyear ice and first-year ice provide different habitats for Arctic animals. For example, sea-ice ridges, which form when ice floes crash into each other (just like mountains form when tectonic plates crash together), are unique habitat features that we know very little about. However, we know that sea-ice ridges form more easily when the ice is thinner, so it is likely that the number of sea-ice ridge habitats will increase as multiyear ice is replaced by thinner first-year ice.

With our research, we try to shed some light on the importance of different sea-ice habitats for marine animals. We try to understand 
Figure 1

Comparison of first-year and multiyear sea ice.

(a) Development of sea ice and snow accumulation, showing the transition from first-year to multiyear sea ice. (b) First-year sea ice, and (c) multiyear sea ice have different habitat properties. Size of yellow arrows corresponds to amount of light. Green patches are sea-ice algae.

\section{PHYTOPLANKTON}

Algae that live in the water column, and that are transported with the ocean currents.

\section{TROPHIC LEVEL}

"Who eats whom"-the position of an animal within a food web. Animals feeding on algae are lower in the food chain than animals feeding on both algae and other animals or strictly on other animals.
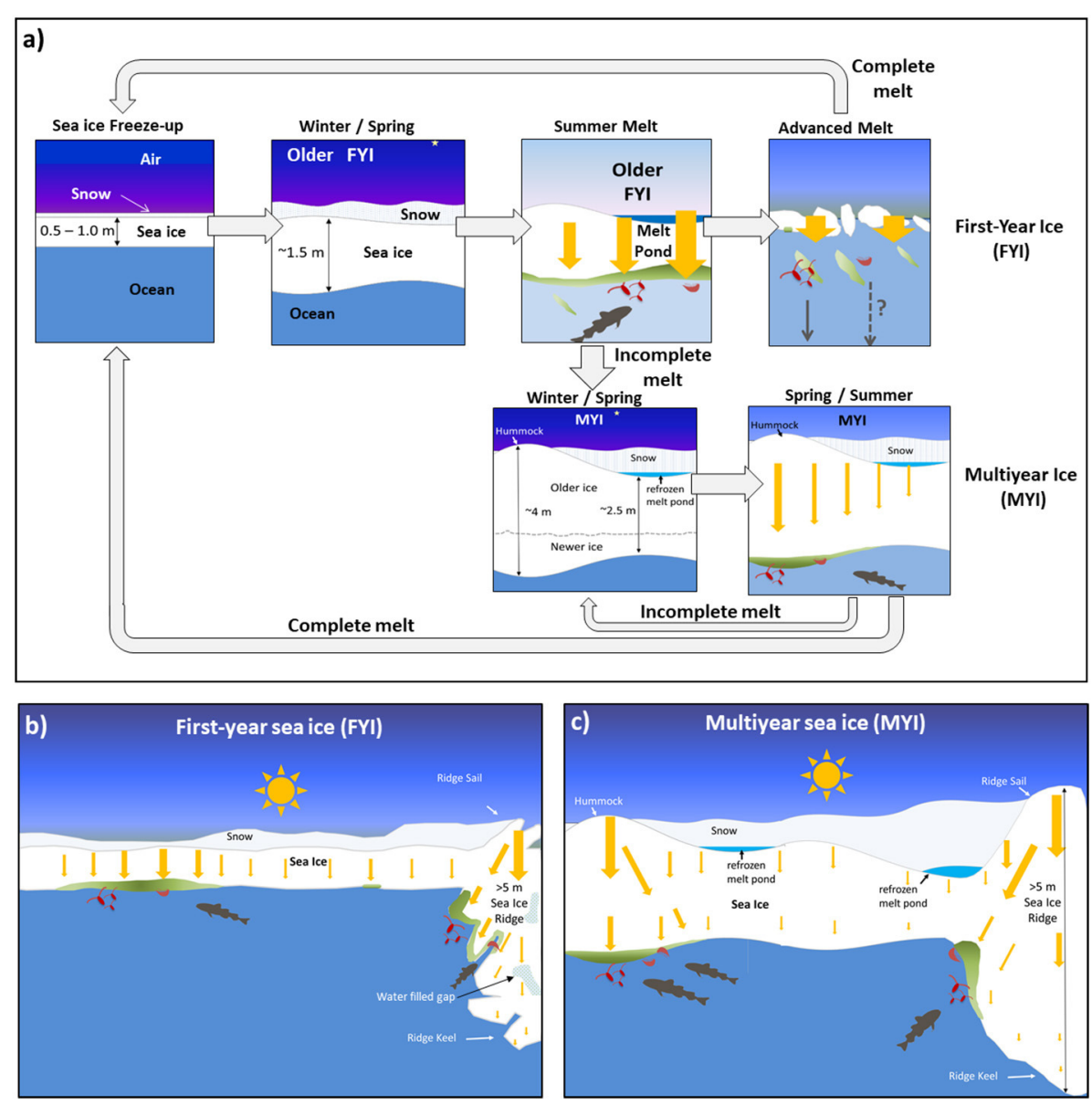

Figure 1

what will be on the grazers' menu if there is less sea-ice algae in the future Arctic Ocean, and how that will impact top predators.

\section{WHO EATS SEA-ICE ALGAE: THE ARCTIC FOOD WEB}

In the Arctic Ocean, sea-ice algae and algae that live in the open water (called phytoplankton) represent the base of the marine food chain. These algae are called primary producers, because they convert energy from the sun into chemicals that can be used by the organisms higher in the food chain, called consumers. After algae, the next trophic level in the food chain includes small animals called zooplankton that feed on sea-ice algae, phytoplankton, or both. Further up the food chain, larger zooplankton feed on smaller zooplankton. These larger zooplankton are a tasty energy source for fish, which are, in turn, on the menu for seals. Lastly, seals are consumed by polar bears. Seals and polar bears are called top predators, which means they represent the endpoints of the food chain. In reality, the interaction of the members of the food chain is a bit messier, because many animals have more than one food source, which is why the who-eats-whom connections are usually called a 
Figure 2

(a) Simplified structure of the Arctic food web. Energy is transferred from the lowest trophic levels to the top predators. (b) Benjamin A. Lange takes sea-ice cores (in the background: German icebreaker Polarstern). (c) Surface and under-ice trawl (SUIT) for sampling organisms living directly underneath the ice. (d) An example of a large zooplankton,

Gammarus wilkitzkii, that is a sympagic amphipod. (e) Polar cod Boreogadus saida feed on copepods and amphipods.

\section{ZOOPLANKTON}

Small marine animals that drift with the ocean current. They are an important link between algae and higher trophic levels by transferring energy along the marine food chain.

\section{PELAGIC}

Lifestyle of animals that spend most of their lives in deep water. Pelagic animals feed on phytoplankton and can also use sea-ice algae as a food source. a)
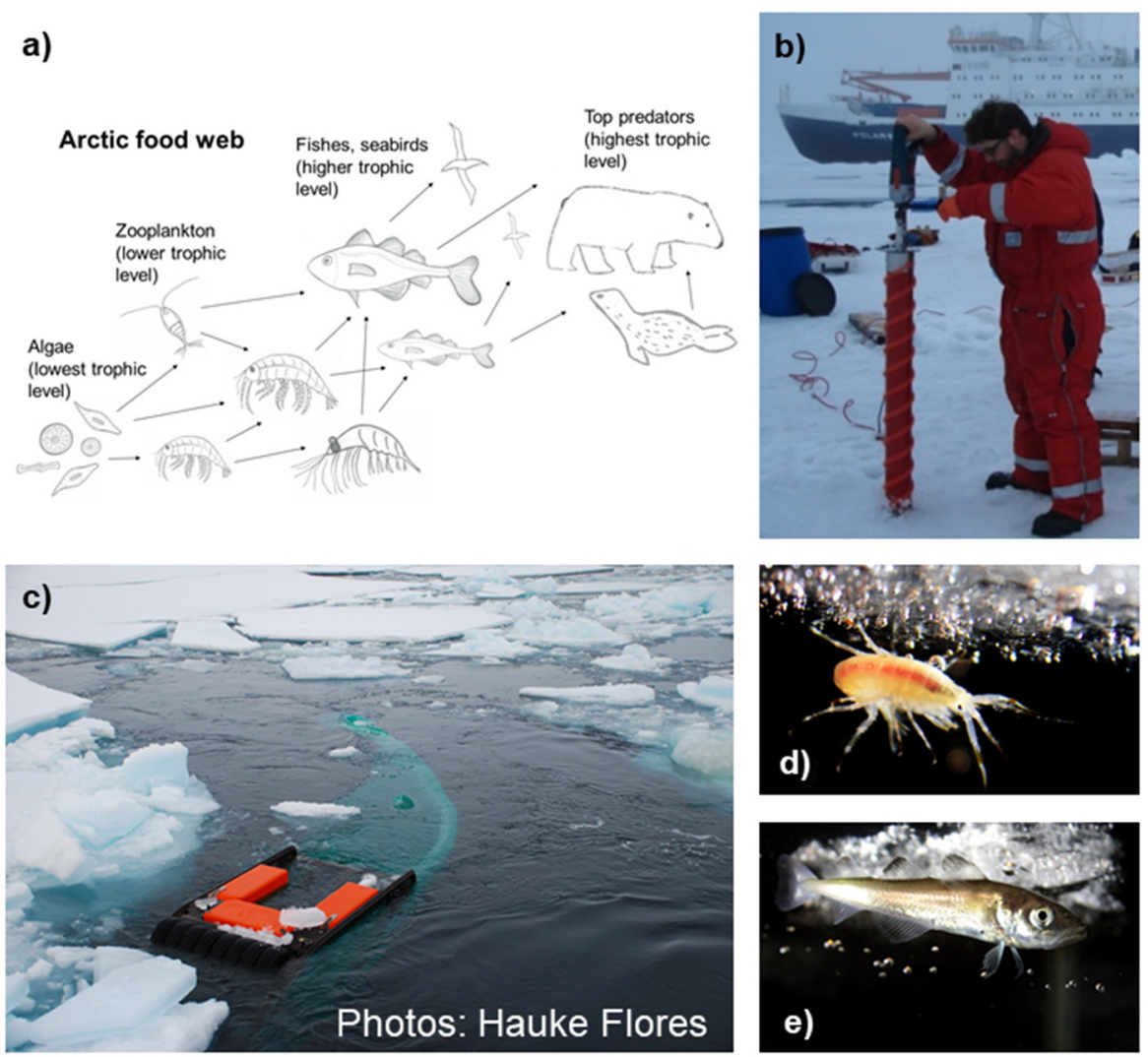

Figure 2

food web (Figure 2a). Within the marine food web, energy is transferred from one trophic level to another in the form of carbon, which is an important component of energy-containing molecules. Top predators are indirectly dependent on sea-ice algae and phytoplankton because the carbon produced by these algae ends up in the top predators' bodies. Almost all processes within the food web are connected to each other. That means, if something changes at the base of the food web, there can be a domino effect all the way up to seals and polar bears.

\section{HOW DO WE KNOW WHAT WE KNOW?}

Polar researchers use ice corers, long tubes with sharp blades at their ends (Figure 2b), to drill holes into the ice to extract sea-ice cores for study. Since sea ice can be several meters thick, drilling ice cores is very time-consuming and labor-intensive! To collect zooplankton and fish, we use nets that are lowered into the water. Some animals live at the sea ice-water interface, directly underneath the ice. These animals can be caught by scuba divers or with special nets that can move directly underneath the ice (Figure 2c). Other zooplankton are pelagic, which means they spend most of their time in the open ocean (NOT near sea ice) at different water depths. To obtain samples from 
seals or polar bears, researchers work closely with local Inuit hunters, who can provide muscle, blubber, and organ samples.

Next, in the lab, we investigate the lipid content in the algae and animals we collect, which can tell us about where the carbon in the animals' bodies originated from. Lipids are fats, and they are made of large carbon-containing molecules called fatty acids. Ice algae and other primary producers make certain fatty acids called marker fatty acids, which are transferred unchanged to animals when the algae are eaten, all the way up to seals and polar bears. Sea-ice algae and phytoplankton can each produce their own set of marker fatty acids. This gives us the great opportunity to distinguish the origin of the carbon in the consumers, meaning we can tell if the organism of interest prefers to eat sea-ice algae or phytoplankton, or a combination of both.

\section{MANY ARCTIC ANIMALS NEED SEA-ICE ALGAE FOR THEIR SURVIVAL}

Most animals have mixed diets and receive their energy from both sea-ice algae and phytoplankton. However, some zooplankton, including small crustaceans called amphipods (Figure $2 \mathrm{~d}$ ), spend most of their lives in close association with sea ice (called a sympagic lifestyle). Sympagic organisms use the sea ice as a place to live, feed, and hide from predators. We found that the carbon consumed by the sympagic amphipod Apherusa glacialis was almost entirely from sea-ice algae [3] (Figure 3). In other words, those animals are almost $100 \%$ dependent on sea-ice algae for their survival! Polar cod (Figure 2e) is an important fish species in the Arctic Ocean, because it is a popular food source for seals and birds. Polar cod can feed on sympagic amphipods, which means this species is also highly dependent on sea-ice algae [4]. Even higher up the food chain, sea-ice algae can be important in the diets of different seals and polar bears $[5,6]$.

\section{WHAT HAPPENS WHEN THE SEA ICE MELTS AND SEA-ICE ALGAE ARE SCARCE?}

Currently, it is a bit tricky to predict how ongoing climate warming will affect the future of marine animals. For many Arctic animals, our knowledge of what, when, and how much they eat is still rather limited. We know that some species are more sensitive to climate change than others, for example sympagic animals. From our results, we can assume that the survival of these ice-associated animals, including those of low and high trophic levels, will be threatened when the sea ice disappears. However, another possibility, and one we can hope for, is that these animals will find a way to cope with the environmental changes, by finding alternative food sources or seeking refuge in 


\section{Figure 3}

Maximum percentage of carbon produced by sea-ice algae in the bodies of various Arctic animals. The amount of carbon was identified using several laboratory methods [3, 4].

Sympagic amphipods are sea ice-associated crustaceans. Pelagic copepods, and other amphipods spend most of their lifecycles at greater depths.

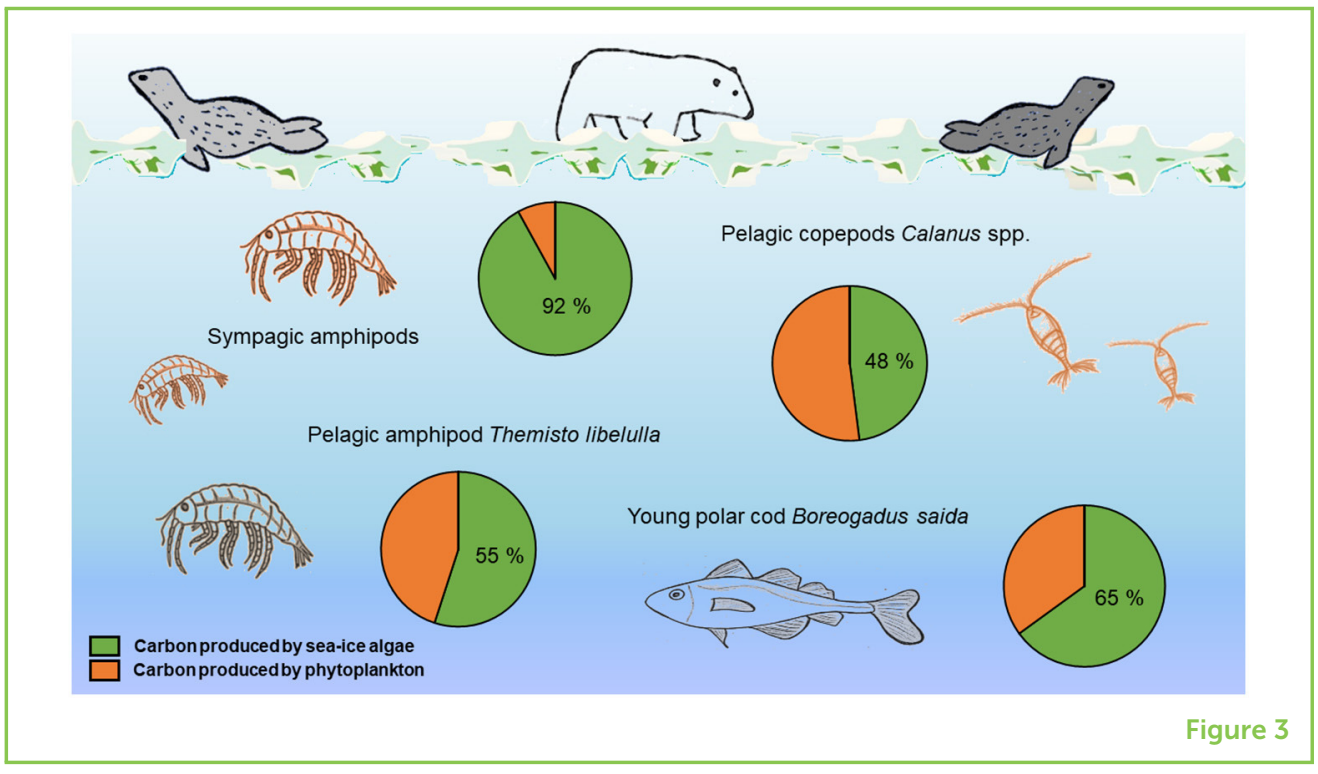

unique sea-ice habitats, such as sea-ice ridges. Studies like ours can help to provide a better overview of the lifestyles of Arctic animals. Our results can be linked to other studies to investigate possible changes specific to a certain region or season. To fully understand the challenges the Arctic food web will face, more information about diets and lifestyles of Arctic animals and their vulnerability regarding environmental changes needs to be collected in future studies.

\section{ACKNOWLEDGMENTS}

This study was part of the Helmholtz Association Young Investigators Group /ceflux: Ice-ecosystem carbon flux in polar oceans (VH-NG-800) at the Alfred Wegener Institute in Bremerhaven, Germany.

\section{ORIGINAL SOURCE ARTICLE}

Kohlbach, D., Graeve, M., Lange, B., David, C., Peeken, I., and Flores, $\mathrm{H}$. 2016. The importance of ice algae-produced carbon in the central Arctic Ocean ecosystem: food web relationships revealed by lipid and stable isotope analyses. Limnol. Oceanogr. 61:2027-44. doi: 10.1002/lno.10351

\section{REFERENCES}

1. Lange, B. A., Beckers, J. F., Casey, J. A., and Haas, C. 2019. Airborne observations of summer thinning of multiyear sea ice originating from the Lincoln Sea. J. Geophys. Res. Oceans 124:243-66. doi: 10.1029/2018JC014383

2. Lange, B. A., Flores, H., Michel, C., Beckers, J. F., Bublitz, A., Casey, J. A., et al. 2017. Pan-Arctic sea ice-algal chl a biomass and suitable habitat are largely 
underestimated for multiyear ice. Glob. Change Biol. 23:4581-97. doi: $10.1111 /$ gcb.13742

3. Kohlbach, D., Graeve, M., Lange, B., David, C., Peeken, I., and Flores, H. 2016. The importance of ice algae-produced carbon in the central Arctic Ocean ecosystem: food web relationships revealed by lipid and stable isotope analyses. Limnol. Oceanogr. 61:2027-44. doi: 10.1002/lno.10351

4. Kohlbach, D., Schaafsma, F., Graeve, M., Lebreton, B., Lange, B., David, C., et al. 2017. Strong linkage of polar cod (Boreogadus saida) to sea ice algae-produced carbon: evidence from stomach content, fatty acid and stable isotope analyses. Prog. Oceanogr. 152:62-74. doi: 10.1016/j.pocean.2017.02.003

5. Wang, S. W., Springer, A. M., Budge, S. M., Horstmann, L., Quakenbush, L. T., and Wooller, M. J. 2016. Carbon sources and trophic relationships of ice seals during recent environmental shifts in the Bering Sea. Ecol. Appl. 26:830-45.

doi: 10.1890/14-2421

6. Brown, T. A., Galicia, M. P., Thiemann, G. W., Belt, S. T., Yurkowski, D. J., and Dyck, M. G. 2018. High contributions of sea ice derived carbon in polar bear (Ursus maritimus) tissue. PLoS ONE 13:e0191631. doi: 10.1371/journal.pone.0191631

SUBMITTED: 06 December 2019; ACCEPTED: 21 July 2020;

PUBLISHED ONLINE: 31 August 2020.

EDITED BY: Penelope Kate Lindeque, Plymouth Marine Laboratory, United Kingdom

CITATION: Kohlbach D and Lange BA (2020) How Melting Arctic Sea Ice Can Lead to Starving Polar Bears. Front. Young Minds 8:111. doi: 10.3389/frym.2020.00111

CONFLICT OF INTEREST: The authors declare that the research was conducted in the absence of any commercial or financial relationships that could be construed as a potential conflict of interest.

COPYRIGHT @ 2020 Kohlbach and Lange. This is an open-access article distributed under the terms of the Creative Commons Attribution License (CC BY). The use, distribution or reproduction in other forums is permitted, provided the original author(s) and the copyright owner(s) are credited and that the original publication in this journal is cited, in accordance with accepted academic practice. No use, distribution or reproduction is permitted which does not comply with these terms.

\section{YOUNG REVIEWERS}

\section{DEVONPORT HIGH SCHOOL FOR GIRLS (11C/2020), AGES: 15-16}

We are a group of enthusiastic Year 11 students studying for our GCSE exams in the summer of 2020 and are really interested in the effects of climate change. We enjoyed finding out more about a career in science from our Science Mentor, Dr. Parry, who used to work in marine science before becoming our biology teacher. 

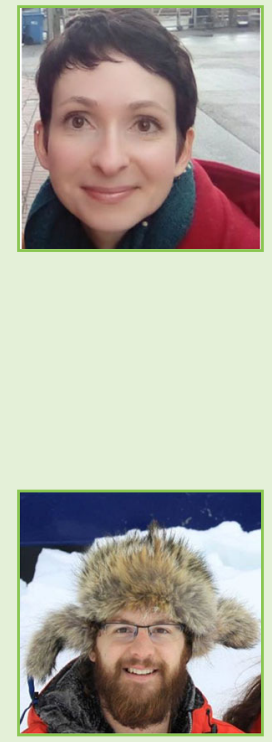

\section{AUTHORS}

\section{DOREEN KOHLBACH}

Doreen is a Marine Biochemist with a scientific interest in polar food web interactions. Doreen was born in Germany, where she also got her Ph.D. To gain work experience abroad, she moved to Canada to study the importance of sea-ice algae for the food web in the Canadian Arctic. Doreen enjoys collecting samples in the field and analyzing them in the lab. Currently, Doreen works at the Norwegian Polar Institute in Troms $\varnothing$, Norway. Here, she is involved in a large Norwegian project to study the consequences of climate change for the food web in the Barents Sea (https: //arvenetternansen.com/). *doreen.kohlbachanpolar.no

\section{BENJAMIN A. LANGE}

Benjamin is a Sea Ice Bio-Physicist, who studies sea-ice habitat properties and consequences of climate change for sea-ice algae. Ben was born in Canada and got his Ph.D. in Germany. Ben's favorite part of being a scientist is participating in research expeditions and writing and publishing research articles in scientific journals. After working at a Canadian research institute, Ben is currently affiliated with the Norwegian Polar Institute in Troms $\varnothing$, Norway. He is part of a huge international project in which the German icebreaker, Polarstern, will freeze into the Arctic sea ice to collect samples for an entire year (https: // follow. mosaic-expedition. org/). 